\title{
ECONOMIC SEGMENTATION, INEQUALITY, AND THE NORTH-SOUTH EARNINGS GAP
}

\author{
Patricia A. Taylor and Patricia A. Gwartney-Gibbs*
}

\begin{abstract}
Segmentation of the work force by industry affects job opportunities and earnings potential, as well as earnings differences between race/sex groups. The structure of the economy, however, is not uniform across the nation, and hence economic segmentation may vary from one region to another. This paper presents data on the nature of segmentation by region and race/sex group in an empirical analysis of the effects of segmentation by region on earnings inequality between race/sex groups.

Using data from the 1978 Current Population Survey, we find that: 1) the earnings gap between the North and South tends to be smallest in the Federal government and largest in the Periphery; 2) earnings inequality between race/sex groups tends to be the smallest in the Federal segment and highest in the Periphery; and 3) the regional difference in earnings inequality by race varies by economic segment, but the difference by sex appears to be unaffected.
\end{abstract}

\section{Introduction}

Earnings inequality by race and sex has been a persistent feature of the American economy (Siegel, 1965; Kreps, 1971; Farley, 1977; Wong, 1982), and large differences in earnings still remain. Attempts to explain race and sex income differences have for the most part focused on identifying and comparing the determinants of earnings, relying on demographic and occupational characteristics of individuals in human capital models.

\footnotetext{
- University of Virginia and University of Oregon. The authors wish to acknowledge support received for Taylor from the National Institute of Mental Health (Grant Number 5T32-MH14598-05); for Gwartney-Gibbs from the Department of Labor (Grant Number G-DD-26-80-025); as well as computer assisted data analysis from the University of Michigan, Ann Arbor. The authors also wish to thank two anonymous reviewers for their comments on an earlier draft of this paper. Analyses and opinions herein are the responsibility of the authors and do not necessarily reflect the views of any Federal agency or personnel.
}

However, the importance of sectoral divisions in the economy as an explanation of earnings inequality has received increasing attention. Since Kerr's (1954) observation of the "balkanization" of labor markets, attempts to define and identify economic segments have generated several similar typologies (e.g., Bibb and Form, 1977; Beck et al., 1978; Hodson, 1978; Oster, 1979; Tolbert, et al., 1980; for reviews see Cain, 1976, and Kalleberg and Sorensen, 1979; for tests of the various typologies see Wallace and Kalleberg, 1981, and Zucker and Rosenstein, 1981). These conceptions generally agree that the economy and/or the labor market is divided into distinct sectors; that the sectors are not equally advantageous to all workers; and that certain groups of workers, such as minorities and women, tend to be concentrated in the least favorable sectors (Bluestone, et al., 1973; Edwards, 1975; Tussing, 1975).

The use of the economic segmentation paradigm is a promising tool in understanding the continuing pervasiveness of earnings inequality. As a heuristic device, however, the economic segmentation thesis is only partially developed, in the sense that several disparate empirical observations on the economy and earnings remain unreconciled. For example, the continuing gap in earnings between regions of the country has remained unaddressed by the segmentation thesis, and unresolved by other theoretical approaches (see Coelho and Ghali, 1971, and 1973; Ladenson, 1973; Bellante, 1979; Stamas, 1981). Secondly, the variation in earnings inequality by race, sex, and region of the country is an observation only recently made, and relatively unexplored by any theoretical explanation (Coelho and Ghali, 1973; Hirschman and Blankenship, 1981). If the economic segmentation thesis is to be as fully developed as both the classical and radical traditions in economics (or functionalist and conflict traditions in sociology), then the logic of the segmentation thesis must be used to explain disparate observations which remain unresolved by alternative paradigms. By using the economic segmentation 
perspective, we analyze and attempt to explain some empirical inconsistencies in the NorthSouth earnings gap by race and sex.

\section{Explanations of the North-South Earnings Gap}

That workers in the South earn less than workers elsewhere has been well-documented (Coelho and Ghali, 1971; Hirschman and Blankenship, 1981). Generally, workers in the South have earnings 12 to 17 percent lower than workers in the rest of the country (Hirschman and Blankenship, 1981; Stamas, 1981). But differences in earnings between Southern and Northern workers are only partially explained by differences in personal characteristics, such as education and experience, or by work factors, such as industry and unionization.

The persistent difference in nominal earnings between the North and South is a wrinkle in the neoclassical perspective of labor economics, or functionalist perspective of stratification. According to these perspectives, ceteris paribus, (1) wage earners should be paid according to their skills and marginal productivity, and (2) labor and capital should both migrate, over the long run, to regions which maximize their respective productivity and return on investments. Therefore, wages for all workers should be equalized once a capitallabor mix is obtained which maximizes labor skills while minimizing labor costs (Borts, 1960). Put differently, as labor and capital become similar across regional lines, a convergence in earnings between the South and North should occur.

Attempts in these theoretical perspectives to explain the North-South earnings gap have been sensitive to factors such as the industry mix for manufacturing workers (Fuchs and Perlman, 1960), occupational and educational skill levels (McKinney and Bourque, 1971), and the racial composition of the work force (Stamas, 1981). Such factors, while important, only partly reduce the North-South earnings gap. In a long-standing debate, Coelho and Ghali $(1971,1973)$ have argued that the NorthSouth earnings gap may be completely eliminated once the cost of living is controlled (however, see Ladenson, 1973). Even so, the North-South gap in real wages varies by cost of living assumptions (Coelho and Ghali, 1973; Ballante, 1979), while the North-South gap in real wage estimates for blacks and women actually increases over the nominal wage model. ${ }^{1}$

In a more radical theoretical perspective of the North-South earnings gap (Myrdal, 1957; Review of Radical Political Economics, 1978), the South is thought to provide migratory streams of cheap labor to the North when opportunity beckons, as well as a reservoir of lowskilled labor for firms which move to the lowwage area. The non-unionized atmosphere and the attitudes of Southern business and civic leaders are said to be responsible, in part, for the lower wages and weak worker protection in the South.

Similar arguments have been offered to explain findings that earnings inequality between blacks and whites is greater in the South than in the North. Hirschman and Blankenship (1981), for example, recently reported that black men who resided in the South earned considerably less than black men in the North; that the earnings gap between black and nonblack males was greater in the South than in the North; and that the absolute dollar difference in earnings between black males in the South and those in the North had actually increased between 1959 and 1975. Similar findings were reported for black and non-black women, although the differences were somewhat smaller. The authors concluded that the greater regional effects on earnings for blacks result from their relative lack of power and their "market" position. That is, blacks' pay seems to be conditioned more by the local job market than by national standards.

But the questions remain: What is the market position of blacks in the South compared to the North? How is it that blacks are more affected by the local labor market? We believe that the answers to these questions lie, to a substantial degree, in the organization of work and the location of workers in various economic segments.

Economic segmentation theory posits a Core sector of the economy, characterized by quasimonopolistic firms and industries which offer their workers relatively high wages and stable employment. Workers' high wages in the Core sector are largely determined by their access to protected internal labor markets within firms, i.e., by "access to different job clusters, by the relatively rigid pattern of wages attached to the job structures through which they respectively move, and by the speed with which they 
pass through those structures" (Gordon, 1972:50). Access to particular job ladders, and even to the segments themselves, are thought to be determined by merit factors such as education and experience. In the Peripheral segment of the economy, in contrast, few job ladders exist, and wages are more directly affected by fluctuations in the general economy than in the Core segment.

Economic segmentation theory suggests that the more an economic segment is governed by rules or is "bureaucratized" (Caplow, 1954; Taylor, 1979; Grandjean, 1981), the greater the likelihood that wage structures are tied to meritocratic principles. Hence, inequality in earnings is less likely to occur when market practices dictate the use of institutionalized rules which measure ability using education and experience. This would necessarily mean that inequality in earnings is less in more rationalized economic segments. Concomitantly, earnings inequality between regions of the country will be observed if there are differences in the concentration of workers by economic segment; e.g., a region which has a greater concentration of workers in bureaucratized segments will demonstrate less inequality of earnings among groups of workers.

On the basis of the foregoing discussion, we hypothesize that:

I. The earnings gap between regions of the country will be smaller within economic segments which are more bureaucratized.

II. The more bureaucratized the economic segment, the less the earnings inequality among groups of workers.

III. The regional difference in earnings inequality among groups of workers will be smaller in the more bureaucratized economic segments.

We turn now to an empirical examination of these arguments.

\section{Data and Methods of Analysis}

The data used in this investigation are from the March 1978 Current Population Survey (CPS). The analysis is restricted to black females, white females, black males and white males ages 25-64, who worked at some time in the prior year and who were not members of the Armed Forces. One result of these selection criteria is that we focus on people who are in their prime working years, eliminating retirees and individuals who are just beginning careers. Another result is that the analysis is not restricted to people who worked continuously in the prior year; rather, we include the large numbers of adults who may have been unemployed or out of the labor force for some part of the year. This last provision allows an important variation between segments, labor supply, to operate freely, and is thus a subject of study in our analysis.

We first divided the sample into four major economic segments. We allocated industries to either the Core or the Periphery segment, following Beck et al. (1978). Employees in the Federal government, and those in the State and Local governments, were placed into two additional economic segments. Core and Federal government segments are similar in that their policies, practices, and bureaucratic structures are national in scope. But the government segment differs in that: (1) the work is predominately service or regulatory-oriented; (2) profitability is not a primary concern as funding is of a political rather than economic nature; (3) many of the regulations and laws which affect government work and workers do not extend to the private sector, and vice versa (O'Connor, 1973; Caplow, 1954); and (4) extensive administrative due-process regulations may afford both blue-collar and white-collar government workers greater protection against unwarranted demotions or layoffs, race/sex discrimination, and managerial whim than many white-collar workers in the Core who remain unprotected by unions, etc. Also, including government workers in the Core might bias race/sex earnings functions, creating the appearance of a greater difference between Core and Periphery workers. State and local governments form a separate economic segment because there is likely to be greater variability in their policies, practices, and bureaucratic structures than is found within the Federal government, especially across regional lines. We use this four-part division of industries rather than a continuous variable (or set of dummy industry variables) so that we can compare differences in earnings by race/sex group and region.

South and North regions of the country were established using the Census classification, in which South includes Alabama, Arkansas, Delaware, the District of Columbia, Florida, Georgia, Kentucky, Louisiana, Maryland, 
Mississippi, North Carolina, Oklahoma, South Carolina, Tennessee, Texas, Virginia, and West Virginia. The remaining states are referred to here as the North.

We next developed a simple earnings determination model (see Farley, 1977 and Tolbert et al., 1980). Within economic segments, regions and race/sex groups, individuals' annual earnings were estimated as a function of education, occupational status, age and age squared, and hours worked. Ordinary least squares were used to determine the partial effects of the independent variables on annual earnings. Coefficients for the independent variables indicate the earnings returns associated with each characteristic.

The dependent variable, annual earnings, was measured as the sum of wage, salary, and self-employment earnings the year prior to the survey 1977.2

The independent variable occupational status is the Duncan (1961) socioeconomic index, which has been found to have a net positive effect on earnings, controlling for education and other predictors of earnings. The scores were assigned on the basis of individuals' current occupations or, if they were not working, their most recent occupation, using detailed Census occupational categories.

Education as a predictor of earnings was estimated as a spline function. That is, years of education was divided into two variables: (1) years of elementary and secondary education (ranging from 0 to 12); and (2) years of postsecondary education (0-6), on the assumption that higher education may be rewarded at a different rate than pre-college education.

Since earnings generally rise with years of labor market experience but at a decreasing rate, two indicators of experience were used: age and age squared. Age is an imperfect measure of work experience, because blacks are known to have more frequent and longer unemployment spells than whites, and women tend to have more intermittent work histories than men. Age and age squared will overestimate actual years of work experience for blacks and women relative to white males. The effect of this imperfect measurement is to bias downwards estimates of earnings returns to experience and to bias upwards earnings returns to schooling (Blinder, 1976; see, however, Rosenzweig and Morgan, 1977). Lacking work history data, we regard age as the most satisfactory proxy for work experience.

As a measure of labor supply, hours worked in 1977 is also used to predict earnings. Hours worked is estimated as the product of the number of weeks worked in the year times the number of hours worked last week. In a labor supply model, this is an important control variable, since women and blacks tend to work fewer hours than white men, and total hours worked has a significant impact on annual earnings. ${ }^{3}$.

\section{Analysis and Results}

The Distribution of Workers. Present in Table 1 is the distribution of workers by region and by

Table 1

Distribution of Workers by South/North Location,

Race/Sex Group, and Economic Segment, 1978.*

\begin{tabular}{|c|c|c|c|c|c|c|c|c|c|c|}
\hline \multirow{3}{*}{$\begin{array}{l}\text { Race/Sex } \\
\text { Group }\end{array}$} & \multicolumn{5}{|c|}{ South } & \multicolumn{5}{|c|}{ North } \\
\hline & \multirow[b]{2}{*}{ Total } & \multicolumn{2}{|c|}{ Government } & \multirow[b]{2}{*}{ Core } & \multirow[b]{2}{*}{ Periphery } & \multirow[b]{2}{*}{ Total } & \multicolumn{2}{|c|}{ Government } & \multirow[b]{2}{*}{ Core } & \multirow[b]{2}{*}{ Periphery } \\
\hline & & Federal & S\&L & & & & Federal & S\&L & & \\
\hline White Males & 8,412 & 348 & 1,002 & 4,592 & 2,470 & 19,947 & 525 & 2,424 & 11,673 & 5,325 \\
\hline$\%$ & 100. & 4.1 & 11.9 & 54.6 & 29.4 & 100. & 2.6 & 12.2 & 58.5 & 26.7 \\
\hline Black Males & 1,451 & 63 & 218 & 693 & 477 & 1,241 & 84 & 198 & 670 & 289 \\
\hline$\%$ & 100. & 4.3 & 15.0 & 47.8 & 32.9 & 100.1 & 6.8 & 16.0 & 54.0 & 23.3 \\
\hline White Females & 5,416 & 162 & 1,055 & 2,050 & 2,149 & 12,598 & 181 & 2,483 & 5,637 & 4,297 \\
\hline$\%$ & 100.1 & 3.0 & 19.5 & 37.9 & 39.7 & 99.9 & 1.4 & 19.7 & 44.7 & 34.1 \\
\hline Black Females & 1,281 & 43 & 331 & 339 & 568 & 1,132 & 48 & 289 & 493 & 302 \\
\hline$\%$ & 100. & 3.4 & 25.8 & 26.5 & 44.3 & 100. & 4.2 & 25.5 & 43.6 & 26.7 \\
\hline Total & 16,560 & 616 & 2,606 & 7,674 & 5,664 & 34,918 & 834 & 5,394 & 18,473 & 10,213 \\
\hline$\%$ & 99.9 & 3.7 & 15.7 & 46.3 & 34.2 & 99.9 & 2.4 & 15.4 & 52.9 & 29.2 \\
\hline
\end{tabular}

- In this and subsequent tables, S\&L refers to state and local governments. 
race/sex group for each of the four economic segments. The heaviest concentration of workers in both the North and the South is the Core segment, but seven percent fewer workers are in the Core segment in the South than are in the Core in the North. Most of these Southern workers are, instead, in the Periphery, which is the least protected, the lowest paid, and the most "casual" of the four segments examined here (Edwards, 1979:167).

Blacks, both male and female, are more likely to work in the Federal, State and Local government sectors than are whites. Females, however, are more likely to work in the Periphery and the State and Local segments, especially in the South, than are either group of males. Differences in the distribution of workers, such as these, across economic segments and between race/sex groups could affect the earnings gap observed between the South and the North.

Average Earnings of Workers. In Hypothesis I, we argued that the earnings gap between the South and North would be least in the most regulated economic segment, i.e., Federal. This segment has institutionalized policies and practices which cross regional lines, so that workers are evenly evaluated across regions. We begin an analysis of Hypothesis I by presenting the average earnings of workers by region, race/sex group, and economic segment in Table 2.
A comparison of South to North earnings provides only limited support to the hypothesized relationships. ${ }^{4}$ The regional earnings gap is the least (i.e., the ratio is largest) in the Federal segment, as hypothesized, for everyone but white females. But only for black males, and to some extent black females, is the gap between the South and North also widest in the Periphery, as hypothesized. For whites there is not much difference in the North-South earnings gap across segments. White males and females receive somewhat higher pay in the North, but the regional ratios vary by no more than four percentage points across segments for both groups.

These findings suggest that there is a race by region by segment effect on the earnings gap, but that a sex effect is, at best, weak. That is, the most rationalized economic segment, Federal, mediates the effect of possible race discrimination in the South, but does little to alleviate earnings inequality by sex, which operates in both the North and South (see Hirschman and Blankenship, 1981:393).

Finally, it should be noted that the NorthSouth earnings gap of 17 percent noted elsewhere (Stamas, 1981) is greatly reduced when economic segment, sex and race are controlled. For whites, the North-South earnings gap is roughly seven percent, suggesting that economic segmentation may greatly affect the earnings distribution of workers.

Table 2

Average Earnings of Workers by Race/Sex Group, Region and Economic Segment, 1978*

\begin{tabular}{|c|c|c|c|c|c|c|c|c|c|c|c|c|}
\hline \multirow{3}{*}{$\begin{array}{l}\text { Race/Sex } \\
\text { Group }\end{array}$} & \multicolumn{4}{|c|}{ South } & \multicolumn{4}{|c|}{ North } & \multicolumn{4}{|c|}{ Ratio of South to North** } \\
\hline & \multicolumn{2}{|c|}{ Government } & \multirow[b]{2}{*}{ Core } & \multirow[b]{2}{*}{ Periphery } & \multicolumn{2}{|c|}{ Government } & \multirow[b]{2}{*}{ Core } & \multirow[b]{2}{*}{ Periphery } & \multicolumn{2}{|c|}{ Government } & \multirow[b]{2}{*}{ Core } & \multirow[b]{2}{*}{ Periphery } \\
\hline & Federal & S\&L & & & Federal & S\&L & & & Federal & S\&L & & \\
\hline White Males & 16,591 & 13,742 & 16,102 & 11,634 & 17,453 & 15,056 & 17,173 & 12,734 & .95 & .91 & .92 & .91 \\
\hline Black Males & 13,570 & 9,709 & 9.664 & 6,869 & 14,860 & 11,944 & 12,366 & 9,938 & .91 & .81 & .78 & .69 \\
\hline White Females & 9,434 & 7,991 & 7,407 & 4,850 & 10,009 & 8,433 & 8,007 & 5,160 & .94 & .95 & .93 & .94 \\
\hline Black Females & 12,480 & 7,440 & 6,890 & 3,849 & 12,383 & 9,706 & 8,527 & 4,922 & 1.01 & .77 & .81 & .78 \\
\hline \multicolumn{13}{|c|}{$\begin{array}{l}\text { Ratio of Group } \\
\text { to White Males*** }\end{array}$} \\
\hline Black Males & .82 & .71 & .60 & .59 & .85 & .79 & .72 & .78 & & & & \\
\hline White Females & .57 & .58 & .46 & .42 & .57 & .56 & .47 & .41 & & & & \\
\hline Black Females & .75 & .54 & .43 & .33 & .71 & .64 & .50 & .39 & & & & \\
\hline
\end{tabular}

*All data are from the 1978 CPS and represent earnings as of 1977 . Earnings of workers in the Federal government have

**All within race/sex group t-tests for South-North differences by economic segment are statistically significant at p $\leq .05$, ***All t-tests comparing white males with each race/sex group by region and economic segment were statistically signific

been adjusted to remove the effect of D.C. employment. except for Black males and Black females in the Federal goverment. ant at $p \leq .05$. 
In Hypothesis II, we posited that earnings inequality between white males and other race/sex groups would be least in the most regulated economic segment. The rules established to evaluate, hire, and promote workers are more likely to operate in a universalistic manner in the Federal segment where matching workers' skills and abilities to particular jobs is most important (Edwards, 1979:167-176 passim).

We find (lower panel of Table 2) that earnings differences by economic segment between white males and the other race/sex groups are as hypothesized in both the South and North. Overall the earnings difference with white males is least for black males, with the smallest difference found in the Federal government for both South and North, as expected. The earnings ratios of females to white males is quite low in both regions, but the hypothesized relationship of segment and earnings inequality is strong, with the smallest differences in the Federal segment and largest differences in the Periphery.

Finally, in Hypothesis III, we stated that the regional differences in inequality between white males and other race/sex groups would be smallest in the most rationalized economic segment. The results indicate only modest support for Hypothesis III. According to the earnings data reported in Table 2 , the regional differences in earnings inequality for blacks and women with white males is smallest for all groups in the Federal segment. But only black males, and to some extent black females, fit the hypothesized pattern of greater regional differences in earnings inequality in the least regulated economic segment, the Periphery. The difference in the earnings ratio across regions for black males who are Federal employees is .03 and for those who are Periphery employees, .19. A weaker pattern of differences is found for black females, with .04 and .06 respectively. White females do not display the hypothesized relationship.

The findings reported above lend support to the usefulness of the economic segmentation perspective. The patterns of the hypothesized relationships exist for most of the comparisons made, although not all comparisons attained statistical significance.

The analysis of average earnings, however, may be affected by regional differences in worker characteristics and variations in the returns to those characteristics by race and/or sex. That is, the earnings gap between regions may be due to worker characteristics rather than the monetary returns to those characteristics. This question is fundamental to studies of inequality, as it is assumed that worker characteristics or investments in education, hours worked, etc., are controlled by the employee, while returns to those characteristics or investments (i.e., pay rates) are controlled by the employer (Taylor, 1979).

The Earnings Determination Model. In order to assess earnings differences within economic segments and across regions, earnings was regressed on the predictor variables discussed earlier for race/sex groups within economic segments and regions. Below we compare the regression results for regions, and then we utilize a regression standardization procedure which allows us to partition earnings between worker characteristics and employercontrolled returns to those characteristics in the North and South, as well as by economic segment. Such an analysis enables a more refined test of Hypotheses II and III.

The regression coefficients of the earnings models for white males presented in Table 3 can be used to compare the differences in rewards to worker characteristics between regions. There appear to be two systematic differences between the South and North. First, the returns to college education are higher in the South than in the North for all economic segments, possibly indicating employers' response to a smaller supply of highly educated workers. Second, among all race/sex groups, the net returns to hours worked are higher in the North than the South (except for Periphery workers), an effect of greater unionization in the North. Similar results were found for hours for the other race/sex groups, and work experience in the North tends to be more highly rewarded than in the South for the other groups.

Less variability between the North and South was found in the regression coefficients for the Federal segment than for the less bureaucratized segments, confirming expectations from Hypotheses II and III. To some extent, this should be expected as General Schedule workers (approximately 60 percent of all Federal workers) are placed on a uniform pay scale. However, blue-collar workers included in our sample of Federal workers are in jobs specifically pegged to local wage scales. To compare the regression coefficients between the North and South we computed two-tailed 
Economic Segmentation, Inequality, and The North-South Earnings Gap

Table 3

Earnings Determination Models by Race/Sex Group, by Region and Economic Segment, 1978.



\begin{tabular}{|c|c|c|c|c|c|c|c|c|c|c|c|c|c|c|c|c|}
\hline \multirow{4}{*}{$\begin{array}{l}\text { Predictor } \\
\text { Variables }\end{array}$} & \multicolumn{7}{|c|}{ North } & \multirow{2}{*}{\multicolumn{5}{|c|}{ WHITE FEMALES }} & \multirow{2}{*}{\multicolumn{4}{|c|}{ BLACK FEMALES }} \\
\hline & \multicolumn{3}{|c|}{ WHITE MALES } & \multicolumn{4}{|c|}{ BLACK MALES } & & & & & & & & & \\
\hline & \multicolumn{2}{|c|}{ Government } & \multirow[b]{2}{*}{ Core } & \multirow[b]{2}{*}{ Puriphery } & \multicolumn{2}{|c|}{ Government } & \multirow[b]{2}{*}{ Core } & \multirow[b]{2}{*}{ Periphny } & \multicolumn{2}{|c|}{ Government } & \multirow[b]{2}{*}{ Cone } & \multirow[b]{2}{*}{ Periphery } & \multicolumn{2}{|c|}{ Government } & \multirow[b]{2}{*}{ Core. } & \multirow[b]{2}{*}{ Periphery } \\
\hline & Federal & S\&L & & & Federal & Sal & & & Federal & Sel & & & Federal & SeL & & \\
\hline Occupational Status & $96.1^{*}$ & $59.5^{*}$ & $83.2^{*}$ & $121.6^{\circ}$ & $69.4^{\circ}$ & $61.9 *$ & $43.9^{\circ}$ & -2.5 & $46.6^{\circ}$ & $22.9^{\circ}$ & $35.2 *$ & $51.5^{\circ}$ & 25.8 & 8.0 & $48.6^{*}$ & 43.5 \\
\hline Education 0-12 & 181.6 & $549.6 *$ & $513.6^{*}$ & $292.1^{*}$ & 134.4 & 265.4 & 127.6 & $463.1 *$ & 531.7 & $205.1 *$ & $177.3^{*}$ & -31.8 & 1600.4 & 296.4 & $320.1 *$ & -41.7 \\
\hline Education +13 & $927.3^{*}$ & 486.3* & $780.1^{*}$ & $710.1^{*}$ & 266.7 & 792.8* & $750.3^{*}$ & 559.9 & $537.8^{*}$ & $739.5^{*}$ & $311.4^{*}$ & $385.1^{*}$ & 181.5 & $1340.3^{*}$ & $206.4^{*}$ & $933.2^{*}$ \\
\hline Age & $1179.3^{*}$ & $1325.9^{*}$ & $1221.8^{*}$ & $926.0^{*}$ & $742.0^{\circ}$ & $630.4^{\circ}$ & $958.1 *$ & $781.5^{*}$ & 351.6 & $112.9^{*}$ & $91.7 *$ & -67.5 & $1800.2^{*}$ & 96.8 & $396.5^{*}$ & $200.7 *$ \\
\hline Age Squared & $-12.1 *$ & $-13.5^{*}$ & $-12.5^{*}$ & $-9.8^{*}$ & $-6.8^{\circ}$ & -5.5 & $-10.5^{\circ}$ & $-9.8^{\circ}$ & $-3.8^{*}$ & -0.6 & -0.8 & $1.0^{\circ}$ & $-20.8^{*}$ & -.3 & -4.2 & $-2.3^{*}$ \\
\hline Hours & $5.6^{*}$ & $3.7^{*}$ & $3.5^{*}$ & $1.7^{\circ}$ & .2 & $5.1 *$ & $\quad 4.0^{\circ}$ & 3.9 & $5.3^{*}$ & $4.0^{*}$ & $3.9 *$ & $2.4^{*}$ & $2.1 *$ & $4.4^{\circ}$ & - $3.3^{\circ}$ & $2.5^{*}$ \\
\hline Intercept & -29703 & -33195 & -28556 & -19237 & -8589 & -19951 & -18963 & -17046 & -15798 & -7084 & -5026 & 927 & -48727 & -7255 & -11458 & -3648 \\
\hline $\mathbf{R}^{2}$ & .414 & .400 & .299 & .217 & .214 & .507 & .306 & .205 & .470 & .521 & .326 & .251 & .258 & .586 & .342 & .436 \\
\hline
\end{tabular}

-p 5.05

t-tests among the coefficients by economic segment and race/sex group." The result for Federal employees in all race/sex groups was that only two of the possible 24 coefficient comparisons were significantly different, indicating little variability in returns to worker characteristics in the Federal segment across regional boundaries. Comparisons of the 24 regression coefficients in each of the other segments resulted in five significant differences for State and Local workers, seven for Core workers, and eight for those employed in the Periphery. This pattern of significant differences suggests that wage determination is more uniform in the highly regulated segments, even though there is considerable variation in the level of pay between states, for example.

To assess the degree of variability in earnings across race/sex groups (Hypothesis III), we use regression standardization. With this method, we can answer such questions as: What would a Southern black female earn in the Periphery if she had the same average characteristics as the average white male in the same economic segment and region? The procedure entails calculating the "hypothetical" earnings of each race/sex group by substitut- ing the average labor force characteristics of white males (see Appendix 1) into the estimated earnings equations for each race/sex group. ${ }^{6}$ If there are no race or sex effects (that is, if employers reward female and black employees at the same rates as white males), then the hypothetical earnings of females and blacks will be identical to the actual earnings of white males. The difference between the hypothetical earnings of a race/sex group (using their own pay structure and white male labor force characteristics) and their actual earnings is a measure of employment discrimination.

The results of the standardization, presented in Table 4, indicate that there are substantial race and sex differences in the pay rates of blacks and females. The hypothetical earnings of these groups are uniformly higher than their actual earnings (compare to Table 2) across regions and economic segments, but considerably lower than white males. If black males, for example, had the same average labor force characteristics as white males, but their own rates of return to those characteristics, they would have earned only $\$ 9,683$ in the Periphery in the South in 1978 , although white males with those same characteristics earned $\$ 11,634$. Instead of earning just one-third of 
Table 4

Hypothetical Earnings for Race/Sex Groups, within Regions and Economic Segments, 1978 Standardized on White Male Labor Force Characteristics.

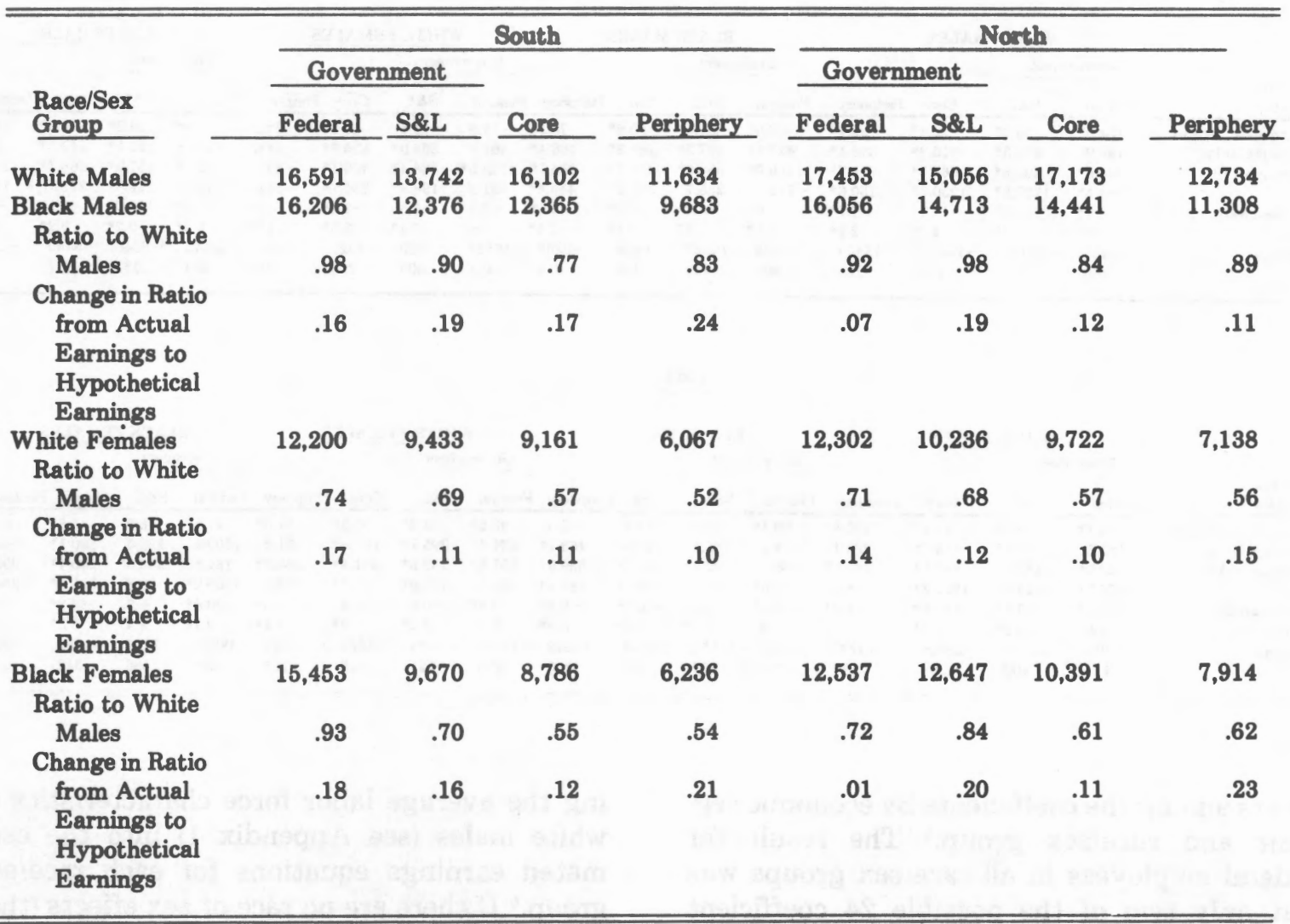

white males' earnings, black females would still have made only 54 percent of white males' earnings if they had the same education, occupational position, etc., as white males. The gains in hypothetical earnings were greater for females of both races than for black males.

We have argued that earnings inequality between race/sex groups should be least in the more rationalized economic segments, because of formalized policies, practices, and work organization which are characteristic of those segments. In standardizing the earnings equations across race/sex groups, therefore, the most highly bureaucratized segment, Federal, should show the smallest difference between the actual and hypothetical earnings of blacks and females. Concomitantly, the Periphery should show the greatest difference.

The results generally support this hypothesis. The difference, or change, in the actual earnings ratio (of black males, white females, and black females to white males) compared to the hypothetical earnings ratio is at least slightly higher in the Periphery than in Federal in almost all instances. The smallest change in actual to hypothetical earnings as a ratio with white males is generally in the Federal segment (especially in the North) or the Core, both of which reference national labor markets and have relatively formalized employment practices. This indicates that pay rates tend to be most equitable (i.e. that discrimination is the least) in these segments.

\section{Discussion and Conclusions}

This analysis of earnings differences has attempted to interpret some disparate observations on earnings by using the economic segmentation perspective. The central argument from the economic segmentation perspective for our purposes is that, along with the concentration of certain industries and their associated labor markets into specific economic segments, there is a relationship between the labor markets and the organization of work. In 
other words, certain types of work require certain types of organization in the labor market.

When an economic segment and its associated labor market are organized hierarchically with job ladders, retention rights, job evaluation procedures, etc., we can speak of a bureaucratically organized economic segment. Such segments are composed of industries which tend to have heavy investment in physical capital and/or organizational development. In order to operate and maintain such physical equipment, and in order for workers to become integrated into the organizational network, jobs are evaluated with respect to immediate tasks as well as to long-run organizational needs, rationally matching workers and tasks. Hence, the earnings of workers in bureaucratic segments should be highly regularized.

On the other hand, less bureaucratized economic segments are less likely to have regularized pay schedules, and are less likely to match workers, abilities, and tasks (see Edwards, 1979:167-168). Moreover, the less bureaucratized segments are more likely to be affected by local market conditions, because their rules and procedures are developed separate from, and are not tied formally to, the rules and procedures of a national labor market.

By conceptualizing four economic segments which vary in their degree of bureaucratization, we have provided a basis for examining the ability of the economic segmentation perspective to explain seeming irregularities in the earnings of workers. We have stressed the Federal and Periphery segments in the analysis, because they are clearly the most and least bureaucratized segments respectively. How the Core and State and Local (S \& L) segments should be ordered between the Federal and Periphery segments remains an open question. The S \& L segment is clearly tied to the Federal segment in employment policies (via various public laws and grant-in-aid programs), but the actual practices of the multitudes of state and local governments are likely to vary considerably. The Core, on the other hand, may be more bureaucratized than the $\mathrm{S}$ \& $\mathrm{L}$ segment, to the extent that it operates in a national labor market, but it is not as likely to be tied to Federal employment policies. The relative ordering of the Core and S \& $\mathrm{L}$ segments awaits further analysis.

With respect to the hypotheses posed earlier, our findings may be summarized as follows:

(1) The regional gap in earnings is smallest in the most bureaucratized segment (Federal) for most race/sex groups and is largest in the least bureaucratized segment (Periphery), especially for blacks.

(2) Earnings inequality between white males and other race/sex groups tends to be lowest in the Federal segment and highest in the Periphery.

(3) The regional difference in earnings inequality by race varies by economic segment, but the difference in earnings inequality by sex appears unaffected.

These findings suggest that differences in earnings between residents of the North and South, and between blacks and whites, may be better explained by their relative access to specific labor markets with meritocratic personnel practices, rather than by employer prejudice, differences in qualifications, or simple regional variations in wages. It is not so much that blacks are "more affected" by the local job market, as suggested by Hirschman and Blankenship (1981) but rather that blacks are positioned in markets which are local in character (i.e., that are more likely to cause aggregate differences in earnings between blacks and whites). We conclude by suggesting that the economic segmentation perspective might usefully be applied to other anomalies in the study of earnings determination, stratification, and inequality.

\section{FOOTNOTES}

${ }^{1}$ Moreover, if wages and cost of living are causally related such that cost of living determines what wages workers will accept (cost-pull rather than demand-push), then wage models which control for cost of living have the same variable on both sides of the equation. Additionally, real wage estimates obtained using cost of living deflators for a "family of four" might introduce a source of bias in that birth rates and household size vary by region of the country. If the use of a cost of living deflator is selected on the basis of what a family needs for maintenance, then family size, which is higher in the South, might also arguably be included.

'Estimates were obtained using both a logged and unlogged earnings variable, but the explained variance was systematically lower in the logged model. Moreover, the logged estimates do not differ in the pattern of results. Hence, we present the untransformed estimates (but see Beck et al., 1978, 1980; Hauser, 1980).

'Certainly, hours worked also reflects labor demand, but for assessing earnings inequality by race and sex, the conservative test is to control hours worked as if it were a pure supply variable.

'Since our interest is in comparing groups of workers by segment, we do not make cost of living adjustments as noted elsewhere.

'The results of the t-tests are available on request, but are not presented here.

'Specifically, the mean values of the earnings predictors 
for white males presented in Appendix 1 are multiplied by the regression coefficients for the same predictors in Table 3 and then are summed, with the intercept, for each race/sex group.

\section{REFERENCES}

Beck, E. M., P. M. Horan, and C. M. Tolbert, III (1978). "Stratification in a dual economy: a sectoral model of earnings determination." American Sociological Review 43 (October): 704-720.

(1980) "Social stratification in industrial society: further evidence for a structural alternative." American Sociological Review 45 (August): 712-719.

Bellante, D. (1979). "The North-South differential and the migration of heterogeneous labor." American Economic Review 69 (March): 166-175.

Bibb, R. and W. H. Form (1977). "The effects of industrial, occupational, and sex stratification on wages in bluecollar markets." Social Forces 55 (June): 974-996.

Blinder, A. S. (1977). "On dogmatism in human capital." Journal of Human Resources 11 (Winter): 8-22.

Bluestone, B., W. M. Murphy, and M. Stevenson (1973). Low Wages and the Working Poor. Policy Papers in Human Resources 22. Ann Arbor, Michigan: Institute of Labor and Industrial Relations, University of Michigan.

Borts, G. H. (1960). "The equalization of returns and regional economic growth." American Economic Review 50 (June): 319-347.

Cain, G. G. (1976). "The challenge of segmented labor market theories to orthodox theory: a survey." Journal of Economic Literature 14 (December): 1215-1257.

Caplow, T. (1976). The Sociology of Work. New York: McGraw-Hill.

Coelho, P. R. P. and M. A. Ghali (1971). "The end of the North-South wage differential." American Economic Review 61 (December): 932-937.

(1973). "The end of the North-South wage differential: reply." American Economic Review 63 (September): 757-762.

Corcoran, M. and G. J. Duncan (1979). "Work history, labor force attachment, and earnings differences between the races and sexes." Journal of Human Resources 14 (Winter): 3-20.

Duncan, O. D. (1961). "A socioeconomic index for all occupations." In Occupations and Social Status, A. J. Reiss, Jr. (editor). New York: Free Press of Glencoe.

Edwards, R. C. (1975). "The social relations of production in the firm and labor market structure." In Labor Market Segmentation, R. Edwards, M. Reich, and D. Gordon (editors). Lexington, Massachusetts: D. C. Heath. Pp. 3-26.

(1979). Contested Terrain. New York: Basic Books.

Farley, R. (1977). "Trends in racial inequalities: Have the gains of the 1960s disappeared in the 1970s?" American Sociological Review 42 (April): 189-208.

Fuchs, V. and R. Perlman (1960). "Recent trends in southern wage differentials." Review of Economic Statistics 42 (August): 290-300.

Gordon, D. (1972). Theories of Poverty and Underemployment. Lexington, Massachusetts: Heath.

Grandjean, B. D. (1981). "History and career in a bureaucratic labor market." American Journal of Sociology
87 (March): 1057-1092.

Hauser, R. M. (1980). "On 'Stratification in a dual economy'." American Sociological Review 45 (August): 702-712.

Hirschman, C. and K. Blankenship (1981). "The NorthSouth earnings gap: changes during the 1960 s and 1970s." American Journal of Sociology 87 (September): 388-403.

Hodson, R. D. (1978). "Labor in the monopoly, competitive, and state sectors of production." Politics and Society 8: 429-480.

Kalleberg, A. L. and A. B. Sorenson (1979). "The sociology of labor markets." In Annual Review of Sociology, Volume 5, A. Inkeles (ed.). Palo Alto, California: Annual Reviews, Inc. Pp. 351-379.

Kerr, C. (1954). "The balkanization of labor markets." Labor Mobility and Economic Opportunity: Essays. E. W. Bakke (editor). Cambridge: Massachusetts Institute of Technology. Pp. 92-100.

Kreps, J. (1971). Sex in the Marketplace. Baltimore, Maryland: Johns Hopkins University Press.

Ladenson, M. L. (1973). "The end of the North-South wage differential: comment." American Economic Review 63 (September): 745-756.

McKinney, M. C. and L. B. Bourque (1971). "The changing south: National incorporation of a region." American Sociological Review 36 (June): 399-412.

Myrdal, G. (1957). Rich Lands and Poor: The Road to World Prosperity. New York: Harper and Row.

O'Connor, J. (1973). The Fiscal Crisis of the State. New York: St. Martin's.

Oster, G. (1979). "A factor analytic test of the theory of the dual economy." Review of Economics and Statistics 61 (February): 33-39.

Review of Radical Political Economics (1978). Special issue: Uneven Regional Development. Volume 10 (Fall).

Rosenzweig, M. R. and J. Morgan (1976). "An exchange on the appropriate specification of human capital models: wage discrimination." Journal of Human Resources 11 (Winter): 3-7.

Siegel, P. M. (1965). "On the cost of being a Negro." Pp. 727-743 in E. O. Lauman, P. M. Siegel and R. W. Hodge (editors), The Logic of Social Hierarchies. Chicago: Markham.

Stamas, G. D. (1981). "The puzzling lag in southern earnings." Monthly Labor Review 104 (June): 27-36.

Taylor, P. A. (1979). "Income inequality in the Federal civilian government." American Sociological Review 44 (June): 468-479.

Tussing, A. D. (1975). Poverty in a Dual Economy. New York: St. Martins.

Tolbert, C. M. III, P. M. Horan, and E. M. Beck. (1980). "The structure of economic segmentation: A dual economy approach." American Journal of Sociology 85 (March): 1095-1116.

Wallace, M. and A. L. Kalleberg (1981). "Economic organization of firms and labor market consequences: toward a specification of dual economy theory." In Sociological Perspectives on Labor Markets (Ivar Berg, editor). New York: Academic Press. Pp. 77-117.

Wong, M. G. (1982). "The cost of being Chinese, Japanese, and Filipino in the United States 1960, 1970, 1976." Pacific Sociological Review 25 (1): 59-78.

Zucker, L. G., and C. Rosenstein (1981). "Taxonomies of institutional structure: dual economy reconsidered." American Sociological Review 46 (December): 869-884. 


\section{Appendix 1}

Mean Values of Earnings' Predictor Variables by Race/Sex Group, Region, and Economic Segment, 1978.

\begin{tabular}{|c|c|c|c|c|c|c|c|c|}
\hline Economic Segment & \multicolumn{4}{|c|}{ South } & \multicolumn{4}{|c|}{ North } \\
\hline $\begin{array}{l}\text { Predictor } \\
\text { Variables }\end{array}$ & $\begin{array}{l}\text { White } \\
\text { Males }\end{array}$ & $\begin{array}{l}\text { Black } \\
\text { Males } \\
\end{array}$ & $\begin{array}{c}\text { White } \\
\text { Females }\end{array}$ & $\begin{array}{c}\text { Black } \\
\text { Pemales } \\
\end{array}$ & $\begin{array}{l}\text { White } \\
\text { Males }\end{array}$ & $\begin{array}{l}\text { Black } \\
\text { Males } \\
\end{array}$ & $\begin{array}{l}\text { White } \\
\text { Females }\end{array}$ & $\begin{array}{c}\text { Black } \\
\text { Pemalea } \\
\end{array}$ \\
\hline \multicolumn{9}{|l|}{ Federal } \\
\hline \multicolumn{9}{|l|}{$\overline{\text { Occupational }}$} \\
\hline Status & 57.3 & 42.3 & 59.9 & 57.3 & 52.0 & 35.1 & 53.7 & 49.6 \\
\hline Education 0-12 & 11.7 & 11.2 & 11.8 & 11.7 & 11.7 & 11.5 & 11.9 & 11.8 \\
\hline Education 13+ & 2.3 & 1.2 & 1.3 & 1.1 & 1.5 & 0.8 & 0.9 & 0.9 \\
\hline Age & 43.5 & 41.6 & 42.0 & 36.5 & 43.6 & 45.4 & 41.0 & 38.1 \\
\hline Age Squared & 1998 & 1845 & 1893 & 1423 & 2015 & 2188 & 1824 & 1533 \\
\hline Hours & 2069 & 2132 & 1868 & 2025 & 2071 & 2097 & 1698 & 1971 \\
\hline \multicolumn{9}{|l|}{ State \& Local } \\
\hline \multicolumn{9}{|l|}{ Occupational } \\
\hline Status & 52.3 & 30.7 & 55.8 & 44.3 & 50.1 & 36.4 & 54.5 & 47.4 \\
\hline Education 0-12 & 11.3 & 10.3 & 11.7 & 11.2 & 11.5 & 11.5 & 11.8 & 11.5 \\
\hline Education 13+ & 2.4 & 1.2 & 2.3 & 1.8 & 2.6 & 1.5 & 2.3 & 1.6 \\
\hline Age & 40.4 & 42.1 & 40.0 & 38.7 & 40.2 & 39.8 & 40.6 & 40.3 \\
\hline Age Squared & 1756 & 1914 & 1734 & 1617 & 1746 & 1704 & 1777 & 1729 \\
\hline Hours & 2182 & 2018 & 1730 & 1786 & 2100 & 1892 & 1661 & 1710 \\
\hline \multicolumn{9}{|l|}{ Core } \\
\hline \multicolumn{9}{|l|}{ Occupational } \\
\hline Status & 45.0 & 24.6 & 49.4 & 32.1 & 44.6 & 29.2 & 46.7 & 38.0 \\
\hline Education 0-12 & 11.1 & 10.0 & 11.5 & 10.9 & 11.3 & 10.8 & 11.6 & 11.4 \\
\hline Education 13+ & 1.4 & 0.6 & 1.0 & 0.6 & 1.5 & 0.8 & 1.1 & 0.8 \\
\hline Age & 40.3 & 39.3 & 39.0 & 36.3 & 41.0 & 39.4 & 40.1 & 37.3 \\
\hline Age Squared & 1748 & 1667 & 1637 & 1413 & 1811 & 1679 & 1738 & 1494 \\
\hline Hours & 2209 & 1857 & 1738 & 1799 & 2153 & 1959 & 1715 & 1769 \\
\hline \multicolumn{9}{|l|}{ Periphery } \\
\hline \multicolumn{9}{|l|}{ Occupational } \\
\hline Status & 35.3 & 19.1 & 33.8 & 18.5 & 34.8 & 26.9 & 34.1 & 23.5 \\
\hline Education 0-12 & 10.5 & 8.9 & 10.6 & 10.0 & 11.0 & 10.4 & 11.1 & 10.4 \\
\hline Education 13+ & 0.8 & 0.3 & 0.4 & 2.5 & 1.0 & 0.6 & 0.6 & 0.2 \\
\hline Age & 40.9 & 41.4 & 41.7 & 40.1 & 41.1 & 38.0 & 41.6 & 42.6 \\
\hline Age Squared & 1808 & 1849 & 1872 & 1751 & 1835 & 1559 & 1870 & 1958 \\
\hline Hours & 2278 & 1795 & 1670 & 1425 & 2218 & 1911 & 1532 & 1520 \\
\hline
\end{tabular}

